REVISTA de

PEDAGOGIE

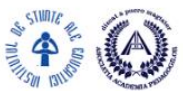

JOURNAL of

PEDAGOGY

http://revped.ise.ro

Print ISSN 0034-8678; Online ISSN: 2559 - 639X

\title{
THE SCHOOL AND THE TEACHER: CHANGES IN STUDENT PERCEPTION DURING THE PANDEMIC
}

ŞCOALA ŞI PROFESORUL: SCHIMBĂRI ÎN PERCEPTJIA ELEVILOR ÎN TIMPUL

PANDEMIEI

Cristian BUCUR, Laura Elena CIOLAN, Anca PETRESCU

Journal of Pedagogy, 2021 (2), 23 - 40

https://doi.org/10.26755/RevPed/2021.2/23

The online version of this article can be found at: https://revped.ise.ro/en/rp-2021-2/

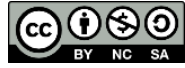

This work is licensed under the Creative Commons Attribution-NonCommercial-ShareAlike 4.0 International License.

To view a copy of this license, visit http://creativecommons.org/licenses/by-nc-sa/4.0/ or send a letter to Creative Commons, PO Box 1866, Mountain View, CA 94042, USA.

Published by:

Centrul Național de Politici și Evaluare în Educație

UNITATEA DE CERCETARE ÎN EDUCAȚIE

https://www.ise.ro/

https://rocnee.eu/

Further information about Revista de Pedagogie - Journal of Pedagogy can be found at:

Editorial Policy: http://revped.ise.ro/editorial-policy/

Author Guidelines: http://revped.ise.ro/en/author-guidelines/ 


\title{
THE SCHOOL AND THE TEACHER: CHANGES IN STUDENT PERCEPTION DURING THE PANDEMIC
}

\author{
Cristian Bucur* \\ Laura Elena Ciolan** \\ Anca Petrescu***
}

\author{
University of Bucharest, \\ Faculty of Psychology and Educational Sciences, \\ Bucharest, Romania \\ cristian.bucur@fpse.unibuc.ro,laura.ciolan@fpse.unibuc.ro, \\ anca.petrescu@fpse.unibuc.ro
}

\begin{abstract}
The relationship between the learning environment and the learning behaviours has long been of interest in educational literature. When addressing the socioemotional stages, Erickson raises awareness of the psycho-social influence of school by way of diligence vs inferiority (Harwood et al., 2010), while Galos and Aldridge (2020) explore how designing a learning environment focused on student self-efficacy triggers statistically significant differences in 4 (out of 9) areas of analysis: fairness, task clarity, learning responsibility and task achievement.

The aim of the present study is to highlight the significance and the differences in the main student psychosocial representations of school and teachers before and during the pandemic, the latter being characterised by government-imposed restrictions as well as changes in the student-teacher interaction, both during the second school term of 2019-2020 and the two school terms of the academic year 2020-2021.

The areas we intend to explore are: overall attitude to school and student emotional

* Lecturer, PhD., Teacher Training Department, Faculty of Psychology and Educational Sciences, University of Bucharest, Bucharest, Romania.

** Senior Lecturer, PhD., Teacher Training Department, Faculty of Psychology and Educational Sciences, University of Bucharest, Bucharest, Romania.

*** Lecturer, PhD., Teacher Training Department, Faculty of Psychology and Educational Sciences, University of Bucharest, Bucharest, Romania. Corresponding author.
\end{abstract}


states, the perception on teacher and peer relations, the perception on school as an organisation but also as a learning environment, the parents as a filter on schoolrelated perceptions, and the projective dimension on school life.

The resulting statistical analysis (both nonparametric tests for independent groups and correlation) reveals major changes in the student perception on school and teachers, which will require systematic future intervention, as well as an upgrade of educational strategies, considering that the approaches designed and applied during the pandemic proved unable to compensate for the changes brought about by the restrictions on learning.

Keywords: pandemic, perception, school, student, teacher.

\section{Rezumat}

Rela ia dintre mediul educa ional şi comportamentele de învă are constituie o preocupare activă a studiilor de specialitate. Dacă Erickson, în stadialitatea socio-emo ională, ne sensibilizează asupra influen ei de natură psiho-socială a şcolarită ii prin sentimentul de sârguin ă versus inferioritate (Harwood et al., 2010), Galos şi Aldridge (2020) eviden iază modul în care crearea unui mediu educa ional focalizat pe o creştere a percep iei autoeficien ei în învă are din partea elevilor generează diferen e semnificative statistic pentru 4 (din cele 9) dimensiuni investigate: echitate, claritatea sarcinilor, responsabilitatea învă ării şi orientarea către sarcină.

La rândul său, lucrarea de fa ă urmăreşte să reliefeze semnifica ia şi diferen ele principalelor reprezentări psihosociale legate de şcoală şi cadrul didactic $\hat{\imath} n$ perioada prepandemică versus cea pandemică, ultima fiind caracterizată de restric iile şi modificările de interac iune stabilite de guvern, care au afectat direct semestrul al II-lea al anului scolar 2019-2020 şi ambele semestre ale anului 2020-2021.

Dimensiunile vizate în studiul nostru sunt: stările afective generale şi atitudinea globală fa ă de scoală, percep ia rela iei cu ceilal $i$ colegi, percep ia rela iei cu profesorul, percep ia şcolii ca institu ie şi clădire, părin ii ca filtru al percep iilor fa $\breve{a}$ de şcoală, dimensiunea proiectivă asupra vie ii de şcolar.

Rezultatele analizei statistice (atât diferen $\breve{a}$ neparametrică, cât şi corela ii) ne determină să afirmăm că schimbările produse în percep ia asupra şcolii şi cadrului didactic sunt majore şi vor impune pe viitor atât o interven ie sistematică, cât şi o actualizare a strategiilor educa ionale, în contextul în care cele deja dezvoltate şi aplicate în perioada pandemică nu au putut compensa modificările produse de restric iile de desfăşurare a şcolii.

Cuvinte-cheie: elev, pandemie, percep ii, profesor, şcoală. 


\section{General background}

The changes that took place in education as a result of the Coronavirus pandemic have triggered multiple, multi-level effects, and have become a recurrent topic in academic writing and research, particularly in what concerns the relationship between online learning on the one hand, and student well-being, learning quality, educational methodology and appropriateness of content and evaluation forms on the other hand (Barnett \& Jung, 2021; Onyema et al., 2020; Pokhrel \& Chhetri, 2021; Tsolou et al., 2021).

Faced with difficult choices, the decision-makers had to take on a crucial role in supporting the education provision and to look for the most effective action plans to address the varied challenges of such a large-scale crisis. Currently, the main objective has to do with minimizing the pandemic harm on schools (Saavedra, 2020) and, at the same time, with rebuilding resilient education systems that would be able to restore the safety and confidence in the capacity of education for regeneration for all teachers, students and their families (UNICEF, 2021).

The present context facilitates in-depth exploration and comparative analysis of all cognitive, psycho-social and emotional strata of education before and during the pandemic, with a focus on the changes brought about by the move towards online schooling.

What has changed and to what extent in the student perception of school and teaching staff? How do they see themselves in relation to the school environment and actual space? Has the tendency to digitalize education impacted significantly the overall attitude of learners towards the purpose and importance of school? Can our students (still) feel good in a school setting?

\section{Research methods}

From this point of view, the starting point of the present study was the pandemic as the background against which education has taken place for over a year and a half. The data was collected both before and during the 
SARS-CoV-2 Coronavirus outbreak, which brought major changes in the global lifestyle and significantly impacted the education systems worldwide.

\subsection{Hypotheses}

In our research, we presumed that there are significant differences in the making of teacher representation based on student age, gender, as well as on-site (pre-pandemic) versus on-line learning in pandemic time (as imposed by government restrictions in March 2020). Taking all this into account, our working hypotheses were as follows:

- Teacher representation changes significantly based on student age and gender.

- The psycho-social representations of school are different before and during the pandemic.

As such, we established that our independent variables would be the age and gender of students as well as the nature of their learning experience before and during the pandemic (further referred to as " 2020 "), while the dependent variable would be the two-fold representation of teacher and school.

\subsection{Research tools}

The research tool for data collection was an opinion survey conducted online, using the Google Form application. The questionnaire was structured on 6 different aspects of school and teacher representation: the overall student emotional states and attitude towards school, the students' perception on teacher and peer relations, the students' perception of school as both an organisation as well as a building, parents as a filter of students' perception on school, the projective dimension on school life. We elaborated between 3 to 8 items for each of these peculiar aspects, while the student relationship with their teachers and schools was comprised of 6 open-ended questions:

a. Which is the most important thing that you feel you learned in school?

b. Do you feel understood by your teacher?

c. If anything bad happens to you at school, who do you tell first? 
d. If you could spend more time at school with your teacher(s), how long would that be and what activities would you like to do?

e. What should your teacher do so that you are happier at school?

f. What should your classroom be like so that you are happier at school?

In the present study, we focused exclusively on responses to these 6 openended questions, which are meant to explore the relationship between child or adolescent and both school and learning, typically mediated by teachers. The other aforementioned 5 dimensions were not taken into account for the analysis.

The answers were provided directly by students, as confirmed by the teachers and parents who volunteered to take part in this research, as effective intermediaries between the questionnaire and its actual respondents.

\subsection{Target group}

The questions were answered by Romanian primary and secondary school students, across ages and genders. All the respondents had equal access to online education, in accordance with the emergency measures and the official regulations implemented by the Ministry of Education. After discarding errors and incomplete answers, we ended up with a final number of 793 participants, distributed unevenly into two different groups: pre-pandemic (before March 2020) and pandemic (after March 2020), and sharing the following characteristics:

Table no. 1. Demographics

\begin{tabular}{|c|c|c|c|c|c|c|c|c|c|}
\hline $\begin{array}{c}\text { Age } \\
5-7 \\
\text { years }\end{array}$ & $\begin{array}{c}\text { Age } \\
8 \\
\text { years }\end{array}$ & $\begin{array}{c}\text { Age } \\
9-12 \\
\text { years }\end{array}$ & $\begin{array}{c}\text { Age } \\
13-14 \\
\text { years }\end{array}$ & $\begin{array}{c}\text { Age } \\
15-16 \\
\text { years }\end{array}$ & $\begin{array}{c}\text { Age } \\
16-18 \\
\text { years }\end{array}$ & Female & Male & $\begin{array}{c}\text { Before March } \\
2020\end{array}$ & $\begin{array}{c}\text { After March } \\
2020\end{array}$ \\
\hline 327 & 77 & 267 & 61 & 16 & 45 & 368 & 425 & $\begin{array}{c}297 \\
(193 \mathrm{~F}, 104 \mathrm{M})\end{array}$ & $\begin{array}{c}496 \\
(175 \mathrm{~F}, 321 \mathrm{M})\end{array}$ \\
\hline
\end{tabular}

Ages were grouped based on development traits, anticipating the presumed differences in perception of school and teacher from one age to another. The 
grouping criteria is also relevant from the class level point of view (e.g., 5 to 7 years-olds are in Reception class and 1st grade, taking the first steps into formal schooling), which is consequently related to the teacher, the experience within the group, the specific learning mechanisms and the type of educational activity. However, the investigated lot should not be considered a sample due to the lack of systematic criteria of description and the volunteer-based data collection.

\section{Findings and results}

To begin with, the data analysis involved a qualitative answer analysis as well as generating the categories of psychological significance in the openended answers. These categories were coded and analysed by descriptive and inferential analysis, for each of the 6 items.

The analysis started off with the potential statistical significance of group differences (based on the independent variables and the groups established within them) and was concluded by a descriptive stage, where psychological significance was added to the findings.

\subsection{Inferential analysis}

Based on data specificities, we used nonparametric tests for our inferential analysis, in particular the Kruskal-Wallis test, which was proposed by the preliminary data analysis by Statistical Package for the Social Sciences (SPSS). The cut-off test significance was 0.05. Not all items provided statistical differences and not on all independent variables. The table below describes only the items where statistical analysis rejected the null hypothesis:

Table no. 2. Items and Variables with statistical difference

\begin{tabular}{|c|c|c|c|c|c|c|}
\hline Independent Variable - Item & Item a. & Item b. & Item c. & Item d. & Item e. & Item f. \\
\hline Gender & $>0,05$ & 0,04 & 0,05 & $>0,05$ & $>0,05$ & $>0,05$ \\
\hline Age & 0,00 & 0,00 & 0,00 & $>0,05$ & 0,02 & 0,00 \\
\hline Pre-pandemic - pandemic & 0,00 & 0,00 & 0,00 & $>0,05$ & 0,00 & $>0,05$ \\
\hline
\end{tabular}


As shown in the table, the variables with the biggest differences were age and pandemic-related. The gender variant was statistically significant for only two items:

- Do you feel understood by your teacher?

- If anything bad happens to you at school, who do you tell first?

This first glimpse at results highlights a few initial findings: firstly, that some variables prove more productive in discriminating the changes in how students perceive teachers; these variables are age and pandemic - "2020". It turns out that gender differences only impact to a small extent the representation of student-teacher relations, despite the fact that gender representations are in full development at the ages under analysis.

A major discrimination criterion is undoubtedly age itself, as an expression of development significance at family, social and socio-educational level. This suggests that the impact of student-teacher relations varies wildly from one age group to another, which needs to be analysed further in terms of the psychological relevance it displays.

The second very productive independent variable - the pandemic "2020" - enables us to put forth the finding that the new types of learning activities - other than face to face and most of them changed into online learning have led to significant changes in the representations of school and teacher. Additionally, if we take into account the relatively short time span of this variable enacting change (approximately 6 months), we can notice the unexpected influence on children and adolescents of the ways learning activities are organized and delivered.

The fact that gender, as an independent variable, discriminated so low between the items suggests that the changes and their impact did not rely on whether a student was a boy or a girl; the adaptive resources of both were just as easy (or hard) to permeate. In other words, representations of teachers differ only slightly depending on gender, and the student-teacher relationship is perceived as being as supportive and significant for both male and female students; it is what ensures an integrated, overall development and leads to similar educational achievements, without the hindrance of potential gender discrimination. 
The variable relating to the pandemic - "2020" - does not seem to discriminate at all between the categories of time and activities spent afterschool (item d.), nor does it impact the way the classroom should look like (item f.) This is particularly interesting as it encourages us to notice that the willingness of students to spend additional time with their teachers is not at all connected to the changes in representations that the move online brought about. Similarly, the significance of the classroom for the student is not overwhelmingly influenced by the shift to online learning.

Moreover, neither does the age variable influence the student's willingness to spend additional time with their teacher in school, after class. The difference between the representation of school and teacher, and the representation of after-school and teacher is inconsistent for the student: the school seems to be an all-encompassing concept, while everything else is probably an administrative issue (connected to time, for instance) or a relational one (teacher-student).

\subsection{Qualitative analysis}

Qualitatively, we have analysed the categories of results per item as percentages, so that the effects of participant differences are reduced. Any differences highlighted in each answer category will be in excess of $10 \%$.

\subsubsection{Item a. Which is the most important thing you feel you} learned in school?

The answers to this item varied substantially: answers that mentioned writing and reading were twice as many (26\%) as those mentioning mathematics $(11 \%)$. In between we can find those referring to social and relational development (18\%). Moreover, the differences in percentage are extremely relevant, depending on the variable categories:

- Learning reading and writing, as well as mathematics, scores as the most important gain for over $70 \%$ of students aged 8-12, but barely achieves an overall of 10\% for ages 13-19.

- Students aged below 7 are highly aware of drawing and generally artistic 
skills (71\%), but these become virtually non-existent for students over 14 years old. A similar scenario takes place with teamwork abilities (only scarcely mentioned over the age of $13-26 \%$, and other interests and hobbies $-11 \%$ ). For students over 13 , these categories score a similar percentage with the "I don't know / I can't tell" answer $-27 \%$.

- In terms of gender, there aren't many notable differences in terms of awareness. The only exception is that $67 \%$ of girls seem to be more aware of learning to work as a team in school, compared to only $33 \%$ of the boys. Other than that, we can safely restate the previous idea according to which the representations of male and female students about school and teacher are similar, and teachers do not typically discriminate based on gender.

- Things are remarkably different for the pandemic variable - "2020": there are differences close to $100 \%$ between the students' perception before and during the pandemic. Starting with 2020 , only $36 \%$ of students seem to realise that they learn to read and write in school (compared to $64 \%$ before 2020). The learning of mathematics almost disappears from school representation: it falls sharply from $81 \%$ before the pandemic, to a mere $19 \%$ during 2020. Practical and artistic skills decrease from $65 \%$ by almost half $-35 \%$, while socializing and friends follow a similar pattern. Perhaps the most significant fact is that school representations seem to get de-structured, as suggested by the increase of "I don't know" answers from $27 \%$ to $73 \%$ in 2020 .

\subsubsection{Item b. Do you feel understood by your teacher?}

- Interestingly enough, positive representations of teacher support and empathy seem to increase in primary school from $25 \%$ (ages 5-7) to $32 \%$ (ages 9-12), however they only reach a total of $13 \%$ for other ages. Negative representations of teacher support and empathy hit a peak at 8-, 9-12-, and 13-14-year olds (over 60-70\%).

- Yet again, gender does not seem to inform major difference in the answers of girls and boys, especially when they are phrases as categorical yes/no assertions. There is, however, one notable exception: boys tend to feel less understood overall (66\%), compared to only $33 \%$ of the girls who share this feeling. 
- The pandemic reveals a negative polarization of teacher representations as emotional support and balance, as well as the basis of social exploration. 2020 marks a reduction by half in positive answers (36\% compared to $64 \%$ before 2020 ), while the categorically negative answers more than double (68\% compared to $32 \%$ before 2020 ).

3.2.3 Item c. If anything bad happens to you at school, who do you tell first?

- This item further explores the significance of the meaningful relationship between student and teacher, with the adult support, confidence and representation as a point of reference. It is a relationship that provides safety and attachment to school and specific activities. From the answers, we can notice an overall $47 \%$ of students show trust in their teachers, followed by $16 \%$ who would first tell their mothers and $1 \%$ who would share their misfortunes with their fathers.

- In terms of age, confidence in the teacher is at a peak between 9 and 12 years $(33 \%)$, with a total of $89 \%$ for ages 5-12. By contrast, in the following 7 years (12-19), only $10 \%$ of adolescents would trust their teachers enough. Trust placed in adults decreases dramatically after the age of 13 (from $10 \%$ of students who would reach out to their mothers to $3 \%$, or from $5 \%$ who would reach out to teachers to $4 \%$ ). However, there is an increase in confidence placed in peers (from 15\% to 19\%).

- Hiding emotionally unsettling events seems to be on the increase between 9 and 14 years, with a total of $66 \%$. The high percentage suggests that this is an extremely vulnerable age group, with obvious needs for counselling and socioemotional support. In contrast, only $16 \%$ of students aged 15-19 would keep school adversity as a secret.

In what concerns gender, there are some specific differences, although there are no significant overall discrepancies between male and female representation of trust and safety:

- Girls tend to find it easier to get close to their teachers (56\% of girls would reach out to a teacher compared to $44 \%$ of boys), but they would only seldom rely on their father (only $21 \%$ of girls would reach out to the male primary care, compared to $79 \%$ of boys). Additionally, more girls 
regard peers as significant support than boys (62\% of girls compared to $38 \%$ of boys). The data also reveals the fact that boys tend less to look for external support, relying instead mainly on the father figure $(79 \%$ boys compared to $21 \%$ girls).

In terms of the pandemic variable, the findings reveal, first of all, a substantial decrease in the teacher role for support, together with that of the parents, while the other sources of confidence and safety stay relatively the same as before 2020: the percentage of students that would reach out to a teacher diminishes by half after 2020 (from 68\% before the pandemic to $32 \%$ ). Similarly, the support of the father figure falls sharply from $71 \%$ to $29 \%$, while slightly more students would reach out to their mothers instead (53\% compared to $47 \%$ before the pandemic). Interestingly enough, students stop looking for support in any other school staff - headteacher, other class teachers (there is a stunning change from $100 \%$ to $0 \%$ ), while reaching out to peers also shifts negatively from $57 \%$ to $43 \%$.

3.2.4 Item d. If you could spend more time at school with your teacher(s), how long would that be and what activities would you like to do?

This item was aimed at highlighting the student-teacher relationship and its strength beyond the timetabled classes that one has to attend.

The age variable shows that the willingness to stay for after-school activities is the biggest for ages 9-12. A similar percentage (around 10\%) of students would show the same willingness around age 8 , but that decreases drastically (by up to three to ten times) for ages 13-19. Nevertheless, a significant number of students would be willing to spend their entire day in school (37\%), but only at around 8 years of age. There is also the negative extreme, with a good number of students who are not willing at all to spend extra time in school: $26 \%$ of 8 -year-olds and $29 \%$ of 9-12-year-olds.

Gender seems an interesting variable for this item.

- There are twice as many girls than boys who would be willing to spend their entire day at school (67\% of girls compared to $33 \%$ of boys), even if for those students who are not willing at all to spend extra time in school, gender is almost irrelevant (46\% of girls and $54 \%$ of boys). 
- The most notable are the differences in activities and school subjects that each gender displays: boys are more interested in mathematics and science (75\% compared to only $25 \%$ ), while girls would stay over time to do activities such as painting, modelling or other practical skills (63\% of girls compared to $38 \%$ boys), languages and communication ( $73 \%$ of girls compared to $27 \%$ of boys). An almost equal number of girls and boys would stay longer for physical activities (46\% of girls and $54 \%$ of boys).

What did the pandemic restrictions in learning organisation and delivery bring about? Here are the differences of more than $10 \%$ :

- There is a dramatic fall in the overall student interest in mathematics and science, from $83 \%$ before 2020 to $17 \%$ after that. An identical decrease can be noticed in practical and artistic skills (from $83 \%$ to $17 \%$ ), and a very similar one as well for languages and communication (from $82 \%$ to $18 \%$ ), while the shift of interest in physical activities is reduced from $67 \%$ to $33 \%$.

- Additionally, only $22 \%$ of students would be now willing to spend the entire day at school compared to the $78 \%$ of students before 2020 (prepandemic times), whereas the percentage of students who would not be willing at all to stay overtime stays relatively the same during the pandemic. The same tendency can be noticed among students who would be willing to stay a few hours (3-4 hrs) longer: their numbers drop to half during the pandemic (71\%-28\%, respectively $62 \%-38 \%)$.

- However, there is a steady percentage of students who are willing to stay 1 or 2 hours longer at school (59\% of students before 2020 compared to $41 \%$ after 2020 , respectively $51 \%-49 \%$ ).

We could therefore say that the effect of restrictions on the student's willingness to stay longer in school is the more noticeable the longer the additional times potentially spent with the teacher (there is an average decrease of 50\%). The percentage of students who do not find any motivation to spend extra time in school stays the same as before the pandemic.

3.2.5. Item e. What should your teacher do so that you are happier at school?

The independent variable of age shows that 9-12-year-olds (51\%) would be 
happier if less homework were assigned. Younger students (5-7 years of age) say that their teacher should smile more (32\%), which totals up to $80 \%$ of the answers up to 12 year olds. The need for reading is very significant at $8(33 \%)$, as well as that for play (37\%). Between 8-12 years of age, students seem to feel that they don't understand enough (a cumulative 37\%). As a result, one of the most present needs is for support from their teacher ("I want them to just sit with me").

Of the students who display a sensitivity towards the teacher raising their voice, the peak age seems to be 8 year olds (30\%), while the overall percentage among 5-9-year-olds totals 50\%.

At the same time, an overwhelming 98\% of students who answered they are (already) happy are between 5 and 12 years of age, reaching a peak between 9-12 years old (44\%).

In terms of age, girls seem to feel the need for more fairness (61\% of girls compared to $39 \%$ of boys). Girls also display a more noticeable need to understand more (70\% of girls compared to $30 \%$ of boys) and refer to themselves as happy more often (67\% versus $33 \%)$.

The pandemic - "2020" decreased the need for play (which reaches only $32 \%$ after 2020 compared to the $68 \%$ it scored beforehand); it also diminished the perceived need for rules (15\% post 2020 compared to $85 \%$ before), as well as the need for the teacher to just sit with me (33\% after 2020 compared to $67 \%$ before). Only $30 \%$ of students (less than half in 2020, compared to the $70 \%$ beforehand) still make a mention of teacher raising their voice, but there are also significantly fewer students who feel already happy (30\% in 2020 compared to $70 \%$ before).

\subsubsection{Item $f$. What should the classroom be like so that you are} happier at school?

The last research item explores the significance of the classroom, which is frequently and heavily influenced by the personality of the teacher and the nature of the relationship between teacher and student. 
We started by considering what the various representations of the classroom are for different age groups, as an extension of teacher personality and school's organizational profile, and we were able to identify the following:

- for 5-7-year-olds, it is important that the classroom is colourful (33\%) and beautiful (34\%);

- for 8 -year-olds, the room must be beautiful $(38 \%)$ and have a lot of visuals $(42 \%)$;

- for 9-12-year-olds, the most important is that the room be clean and tidy (48\%), a place of happy relationships, friends and understanding (38\%);

- most 13-19-year-olds also refer to tidiness, cleanliness and quality relationship. It must also be mentioned that many answers for this age group specify equipment and facilities as being important (22\% in total).

In terms of gender, most girls seem to prefer a colourful classroom (60\% of girls compared to $40 \%$ of boys) and focus more on harmonious relationships ( $57 \%$ of girls compared to $43 \%$ of boys). In other respects, there are only minor differences around $10 \%$.

The pandemic variable generated a significant decrease in all aspects connected to the student perception of the classroom, the most obvious of which refer to the room being beautiful (mentioned by only $34 \%$ of students compared to $66 \%$ before 2020), images and fairies (29\% compared to $71 \%$ before 2020$)$, nicely decorated (34\% compared to 66\%), clean and tidy (39\% compared to $61 \%$ ). The results provide fertile ground for future research on the differences between the physical learning environment and the virtual classrooms of online education.

\section{Discussion}

The findings of this study have to be seen in light of some limitations. First, the study focused on two different groups (pre-pandemic and pandemic) in terms of age and gender distribution, with no analysis of urban/ rural disparities. Second, not all age groups had the same consistency level; for some of them, the low number of valid recorded responses impedes on the strength of evidence in favour of our research hypotheses. 
Nevertheless, the analysis clearly points out that the restrictions on educational activities have had a considerable impact on how students relate to both teachers and the school as whole. Despite their relatively short duration of enforcement, the pandemic-related constraints have reverberated in the chief aspect of school life (by way of comparison, a similar educational shift, the Reception/ Preparatory class year, needed to benefit from years of teacher training, as well as systematic action on parents and students alike).

Our research results show once more that the mental representations of teachers change significantly with the student age, the most sensitive of whom are 9-12-year-olds, who are particularly dependent on their interaction with the teacher.

Furthermore, the student gender influences only partially and to a small extent their mental representation of their teacher, which at the same time highlights the teachers' ability to treat students as developing beings rather than girls or boys who act in specific roles - which comes to show that gender discrimination is virtually non-existent.

There are, however, a few essential elements that need to be addressed by teachers and educational managers and which require immediate, even if not systemic, intervention.

- Student gender determines different needs.

Girls seem to need:

- a physical space that is well equipped and psychologically safe and warm;

- more playful interaction with the teacher;

- their learning organized in different ways, since they feel certain tasks and subjects are more difficult;

- more teamwork.

At the same time, the girls' answers point to the fact that they are happier at school.

As for boys, they:

- feel (almost twice as) pressured by the amount of learning hours and work; 
- state that they "aren't understood" by teachers, which augment maladaptive behaviours and weaken the psycho-social mechanisms that would motivate and mobilize them.

- Student age influences the student relationships with their teacher and peers.

- Even a significant percentage of 5-7 and 8-year-olds state they feel alone and unsupported in various learning tasks, which leads to a negative separation between students and learning activities, as if they are constantly tested against standards they do not quite grasp and therefore don't know how to succeed.

- The teaching style, the quality of the relationship with the teacher and a supportive attitude seem to matter more to 5-7 and 8-year-olds.

- Similarly, peer relationships prove to pose a problem to 9-year-olds, which later decreases from $55 \%$ to $28 \%$.

- Students in the 5-7- and 8-years age groups seem more sensitive to how well equipped the physical space is and how attractive it is, displaying at the same time a substantial need for alternative activities.

- Almost every other student between 6 and 8 years of age would like their teacher to use a softer voice $(52 \%)$ and would need more help to understand things (49\%).

- Every third student between 6 and 8 years of age says they would like their teacher to smile more.

- There is a notable polarisation between students who realise the value of school and learning, and those who are thoroughly under-motivated. This leads to the idea that building and developing an awareness of the importance of education, as well as the efforts that assist this process, have already been established prior to this age and work autonomously further on.

- During the pandemic, there are twice as many students who feel burdened by homework and school activities, over a very short time (one year).

- Many of the students who participated in our study have explicitly stated the need for their teacher to be closer to them and engage in shared activities, which suggests they might have felt abandoned in the face of academic difficulties and issues. Overall, there is an enhanced need for a different kind of learning and teaching, with fewer subjects and less pressure to perform. 


\section{Conclusion}

The results of our research confirm that the measures imposed in the context of the 2020 pandemic have substantially altered the national educational landscape. Besides the age and gender specific needs that were also part of this study, we believe it is essential to consider future interventions that would minimize the harmful effects of the changes brought about by the pandemic, as well as to develop educational programmes that will be suited to the current context. The future of post-pandemic education will depend to a great extent on understanding a new educational paradigm, as well as on the systemic capacity to view these challenges as just as many development opportunities.

\section{References}

- Barnett, W.S., \& Jung, K. (2021). Seven Impacts of the Pandemic on Young Children and their Parents: Initial Findings from NIEER's December 2020 Preschool Learning Activities Survey. National Institute for Early Education Research.

- Galos, S., \& Aldridge, J.M. (2020). Relationships between learning environments and self-efficacy in primary schools and differing perceptions of at-risk students. Learning Environments Research, 24(1), 253-268. https://doi.org/10.1007/s10984-020-09323-0

- Harwood, R., Miller, S.A., \& Vasta, R. (2010). Psihologia copilului. Polirom.

- Onyema, E.M., Nwafor, C.E., Obafemi, F.A., Shuvro, S., Fyneface, G.A., Aabha, S., \& Alhuseen, O.A. (2020). Impact of Coronavirus Pandemic on Education. Journal of Education and Practice, 11(13), 108-121.

https://doi.org/10.7176/JEP/11-13-12

- Pokhrel, S., \& Chhetri, R. (2021). A Literature Review on Impact of COVID-19 Pandemic on Teaching and Learning. Higher Education for the Future, 8(1), 133-141. https://doi.org/10.1177/2347631120983481

- Saavedra, J. (2020). Educational Challenges and Opportunities of the Coronavirus (COVID- 19) Pandemic. World Bank Blogs.

- Tsolou, O., Babalis, T., \& Tsoli, K. (2021). The Impact of COVID-19 Pandemic on Education: Social Exclusion and Dropping out of School. Creative Education, 12, 529-544. https://doi.org/10.4236/ce.2021.123036

- UNICEF (2021). Building Resilient Systems beyond the COVID-19 Pandemic: Second set of considerations for school reopening. UNICEF Europe and Central Asia. 
The online version of this article can be found at: http://revped.ise.ro/category/2021-en/

\section{(cc) EY-NC-SA}

This work is licensed under the Creative Commons Attribution-NonCommercial-ShareAlike 4.0 International License.

To view a copy of this license, visit http://creativecommons.org/licenses/by-nc-sa/4.0/ or send a letter to Creative Commons, PO Box 1866, Mountain View, CA 94042, USA.
Versiunea online a acestui articol poate fi găsită la: http://revped.ise.ro/category/2021-ro/

\section{(cC) DY-NC-SA}

Această lucrare este licen iată sub Creative Commons Attribution-NonCommercial-ShareAlike 4.0 International License.

Pentru a vedea o copie a acestei licen e, vizita $i$ http://creativecommons.org/licenses/by-nc-sa/4.0/ sau trimite i o scrisoare către Creative Commons, PO Box 1866, Mountain View, CA 94042, SUA. 